\title{
TANTANGAN MEMBANGUN MANAJEMEN DAN PENGUKURAN KINERJA SEKTOR PUBLIK DI INDONESIA
}

\author{
*M. Rizki Pratama1) \\ 1) Prodi Administrasi Publik, Fakultas Ilmu Administrasi, Universitas Brawijaya, Indonesia \\ *Email Korespondensi : pratamarizkim@ub.ac.id
}

\begin{abstract}
Abstrak
Manajemen dan pengukuran kinerja di sektor publik pada dasarnya lebih kompleks dibandingkan dengan sektor bisnis. Benturan nilai seperti politik dan abstraknya target kinerja membuat manajemen dan pengukuran kinerja sektor publik memiliki titik distingtif dengan berbagai tantangan yang berbeda pula. Studi ini bertujuan untuk menggambarkan berbagai tantangan yang terjadi dalam konteks membangun manajemen dan pengukuran kinerja sektor publik di Indonesia pasca implementasi Undang-Undang Nomor 5 tentang Aparatur Sipil Negara. Peneliti menerapkan studi literatur dengan melakukan inklusi literatur dengan dua basis utama yaitu masalah internal dan eksternal dalam manajemen dan pengukuran kinerja sektor publik. Pada akhirnya ditemuka empat tantangan yang harus diperhatikan untuk semakin menyempurnakan manajemen dan pengukuran kinerja sektor publik di Indonesia yaitu pengelolaan dampak baik dan buruk manajemen dan pengukuran kinerja, pengelolaan bias dan independensi penilaian kinerja, pengelolaan kinerja pada masa disrupsi dan pandemi serta pengelolaan kinerja generasi milenial.
\end{abstract}

Kata Kunci: Manajemen Kinerja, Pengukuran Kinerja, Sektor Publik, Pegawai Negeri Sipil

\begin{abstract}
Management and performance measurement in the public sector are inherently more complex compared to the business sector. Conflicting values such as politics and abstract performance targets make public sector performance management and measurement have distinctive points with different challenges as well. This study aims to describe the various challenges that occur in the context of developing management and performance measurement of the public sector in Indonesia after the implementation of The Law Number 5 of 2014 concerning Civil Servants. The researcher applied a literature study by conducting literature inclusion on two main bases, namely internal and external problems in management and public sector performance measurement. In the end, there are four challenges that must be considered in order to further improve the management and performance measurement of the public sector in Indonesia, namely managing the good and bad impacts of management and performance measurement, managing bias and independence of performance appraisal, managing performance during times of disruption and pandemic and managing the performance of the millennial generation.
\end{abstract}

Keywords: Performance Management, Performance Measurement, Public Sector, Public Servant 


\section{PENDAHULUAN}

Fungsi Manajemen Sumber Daya Manusia yang banyak menjadi sorotan akhirakhir ini dalam sektor publik adalah bagaimana menunjukkan individu dengan kinerja tinggi dibandingkan dengan individu dengan kinerja rendah, sebab banyak benturan nilai yang terjadi di sektor publik terutama dalam kehidupan nyata birokrasi seperti benturan efisiensi dengan efektivitas serta efisiensi dengan nilai keadilan. Pada dasarnya penilaian kinerja organisasi mebentuk sistem formal terhadap upaya untuk mengkaji kembali (review) dan evaluasi kinerja individu dalam melaksanakan tugas dan pekerjaannya secara terus menerus (Masdar et al., 2009). Evaluasi akan lebih kompleks dan problematik di sektor publik (Lane, 2000). Itulah mengapa penilaian kinerja dianggap lebih sulit untuk dilakukan di sektor publik.

Tantangan kompleksitas telah membuat penilaian kinerja di sektor publik menjadi sulit untuk dilakukan, padahal penilaian kinerja merupakan fungsi yang signifikan dalam mendorong organisasi untuk mencapai tujuannya secara efektif, sangat riskan untuk melakukan operasionalisasi kegiatan organisasi sehari-hari akan tetapi tidak diketahui secara akurat bagaimana performa individu dalam organisasi. Performa individu sangat mempengaruhi arah organisasi maka tanpa adanya penilaian kinerja yang tepat dikhawatirkan organisasi tidak akan bergerak kemana-kemana alias stagnan. Melalui penilaian kinerja lah individu dapat dipantau secara terus menerus prestasinya, menemukan kelemahan dan memperbaikainya serta memberikan reward tertentu atas prestasinya untuk mengharagai individu. Sistem penilaian kinerja juga berhubungan langsung dengan sistem kompensasi dan benefit yang harus memperhatikan keadilan bagi para individu, jangan sampai individu dengan preforma rendah mendapat perlakuan yang sama dengan individu dengan prestasi tinggi, ketika timbul kekecewaan pegawai dipastikan akan menggangu jalannya organisasi dalam waktu yang lama akan membuat organisasi sakit.

Teori-teori dalam berbagai literatur menyebutkan selain terhimpit oleh tantangan kompleksitas sektor publik ternyata penilaian kinerja juga membawa manfaat sekaligus keburukan. Selain dapat digunakan untuk pengambilan keputusan ternyata penilaian 
kinerja tidak mampu menangkap secara komprehensif performa aktual individu sehingga cenderung bias. Selain itu penilaian kinerja akan sangat tergantung pada para penilai yang tidak dapat dipastikan objektifitasnya. Manajemen kinerja juga dapat berbalik arah dengan menutup peluang inovasi dan ambisi (De Bruijn, 2007). Penjelasan tersebut menunjukkan adanya pertentangan yang dilematis antara tujuan positif penilaian kinerja dengan dampak negatif dari penilaian kinerja yang apabila tidak disiasati dengan tepat akan membuat organsisasi justru tenggelam pada efek negatif sehingga gagal menggambarkan performa aktual yang sebenarnya.

Fenemona di Indonesia melalui manajemen dan pengukuran kinerja sektor publik juga mengalamai kondisi serupa yatu performa sulit diukur dan alat ukur yang digunakan juga belum mampu secara tepat menggambarkan realita kinerja Pegawai Negeri Sipil (PNS). Mulai penggunaan daftar penilaian pelaksanaan pekerjaan (DP3) yang dipakai berpuluh-puluh tahun yang dianggap tidak relevan, tidak jelas, subjektif dan tidak transparan dalam mengukur kinerja PNS hingga adanya pembaruan dengan terbitnya aturan sasaran kinerja pegawai (SKP) melalui PP 46 Tahun 2011 yang terus dioptimalkan karena memiliki berbagai kelemahan seperti tergantung pada subjektifitas pimpinan, tidak menggunakan penilaian 360 derajat hingga kurang dilibatkannya pegawai dalam penyusunan SKP secara kolaboratif dengan pimpinannya. Pada masa SKP melalui PP 46 tahun 2011 juga muncul berbagai kritik seperti Thoha menyebutkan bahwa di manajemen kepegawaian ASN di Indonesia ditemukan fakta masih kuatnya pertimbangan senioritas (golongan dan pangkat) dalam promosi ketimbang kompetensi dan prestasi (Miftah Thoha, 2016). Artinya prestasi masih kurang dihargai di birokrasi nasional. Persoalan lain yang masih terkait adalah apakah sistem tersebut telah dibuat dengan keterlibatan pegawai sendiri sehingga menghasilkan sistem yang komprehensif atau sistem yang dibuat secara sentralistik sehingga pegawai mau tidak mau harus menerima sistem yang ada. Di masa yang akan datang, pengukuran kinerja harus melibatkan pegawai sehingga pegawai akan dapat memperoleh gambaran yang jelas mengenai tujuan dan sasaran organisasi (Rosyadi, 2007).

Pada akhirnya PP 46 Tahun 2011 kemudian direvisi kembali melalui PP 30 Tahun 2019 dengan berbagai perubahan signifikan seperti munculnya konsep integrasi penilaian 
kinerja dengan sistem manajemen kinerja sehingga menjadi satu kesatuan, hadirnya pemantauan kinerja untuk dapat mengelola proses pencapaian kinerja, kemudian ditambah dengan munculnya konsep bimbingan kinerja dan konseling kinerja sebagai ruang kolaborasi antara pegawai dan pimpinan dan implementasi sistem informasi kinerja sebagai bahan data utama untuk manajemen kinerja. Meskipun terjadi beberapa perubahan signifikan bukan berarti perubahan tersebut harus berjalan di tempat karena jelas situasi sektor publik dan masyarakat saat ini berubah dengan cepat seperti hadirnya era disrupsi melalui revolusi industri 4.0 dan merebaknya pandemi Covid-19 yang tentu saja merubah berbagai pekerjaan dan performa organisasi.

Oleh karena itu tulisan ini bertujuan untuk memberikan gambaran tentang berbagai tantangan yang terjadi dalam manajemen dan pengukuran kinerja sektor publik terutama sebagai bahan refleksi bagi para policy maker untuk menyempurnakan secara terus-menurus (continous improvement) sistem manajemen dan pengukuran kinerja yang tepat bagi Pegawai Negeri Sipil (PNS) berdasarkan Undang-Undang Aparatur Sipil Negara (ASN) dan sesuai dengan persoalan terkini.

\section{TINJAUAN PUSTAKA}

\section{MANAJEMEN DAN PENGUKURAN KINERJA: PENDEKATAN DAN METODE}

Menurut (Pynes, 2008): there are three general approaches to performance appraisals: absolute, comparative, and goal setting. Ketiga pendekatan tersebut memiliki batasan tersendiri. Pertama, pendekatan absolute hanya menilai kinerja berdasarkan perspektif pegawai sendiri tanpa diperbandingkan dengan pegawai yang lain. Kedua, pendekatan komparatif mencoba membandingkan pegawai yang satu dengan yang lain sedangkan yang Ketiga, pendekatan goal setting mendasarkan pada kontrak tujuan yang telah ditetapkan sebelumnya. Ketiga pendekatan tersebut menciptakan banyak metode dalam penilaian kinerja. Metode sangat penting karena akan menentukan teknis dari penialian kinerja pegawai dan masing-masing metode memiliki tujuan yang tersendiri. Menurut Condrey terdapat dua sistem skala yang seringkali digunakan untuk menilai kinerja individu di sektor publik, pertama yaitu behaviorally anchored rating scales 
(BARS) yang berbasis pada proses bukan pada hasil akhir. Kedua, management by objectives (MBO) yang berbasis hasil akhir. Menurut (Condrey, 2005): Behaviorally anchored rating scales, on the one hand, are ideal for large organizations engaged in process-oriented tasks requiring teamwork. Management by objectives, on the other hand, can be individually tailored to specific job responsibilities (Condrey, 2005). Kedua sistem tersebut memiliki tujuan ideal yang berbeda, BARS akan sangat ideal para organisasi publik yang berorientasi pada proses dan kerjasama tim sedangkan MBO akan ideal pada organisasi yang memiliki tanggungjawab tugas yang spesifik.

Pada dasarnya pendekatan komparatif memberikan metode yang sangat efektif untuk menilai kinerja yaitu menggunakan metode penilaian dengan beberapa penilai sehingga mengurangi subyektifitas para penilai. Menurut (Condrey, 2005): These proposals (components of which are used in 360-degree feedback) fall into two general categories-the use of agency insiders (for example, self-appraisal, peer review, subordinate appraisal, and multiple raters) and the use of outsiders (for example, personnel officials, consultants and assessment centers, and clients and customers). Condrey memberikan beberapa jenis metode dalam penilaian kinerja terutama dalam pendekatan komparatif yang dikenal dengan metode 360 derajat yang menilai pegawai dari keseluruhan individu yang ada di sekitar lingkungan kerja pegawai terutama atasan, bawahan dan rekan sejawat. Condrey juga memberikan tawaran bahwa penilaian dapat dilakukan oleh lingkungan internal maupun eksternal tergantung dari kebutuhan organisasi. Selain itu juga masih terdapat metode lain seperti metode evaluasi kerja yang dikemukakan Bernardin \& Russel yaitu dengan mengelompokkan dalam dua kategori seperti 1) metode kuantitatif yang sering dipakai adalah perbandingan faktor dan point faktor, 2) metode non kuantitatif yang paling umum dipakai adalah kualifikasi dan ranking (Sulistiyani \& Rosidah, 2003).

Mendasarkan pada pendekatan dan metode tersebut maka masing-masing memiliki tujuan tersenederi sehingga sistem penilaian kinerja harus dibuat berdasarkan kebutuhan organisasi publik. Pendekatan yang dapat ditarik sebagai yang paling ideal saat ini adalah pendekatan komparatif yang menciptakan penilaian 360 derajat selain itu juga masih terdapat pilihan mengembangkan sistem penilaian kinerja berbasis proses seperti 
BARS atau hasil seperti MBO. Pendekatan goal setting juga dapat diterapkan jika mengingkan ada kontrak yang spesifik dengan pegawai. Kembali semua harus berbasis kebutuhan dan tidak menciptakan bias penilaian. Tidak ada sistem penilaian kinerja yang terbaik akan tetapi yang ada hanyalah sistem penilaian kinerja yang tepat dengan kebutuhan organisasi.

\section{KOMPLEKSITAS MANAJEMEN DAN PENGUKURAN KINERJA SEKTOR PUBLIK}

MSDM dalam sektor publik tentu memiliki tantangan yang berbeda dengan sektor privat apalagi lingkungan yang dihadapi juga berbeda, struktur organsiasi yang berbeda dan tujuan dasar organisasi berbeda. Perbedaan tersebut menimbulkan kompleksitas atau kerumitan dalam MSDM sektor publik yang tentu saja akan berpengaruh signifikan dalam setiap fungsi-fungsi MSDM seperti penilaian kinerja. Menurut Sulistyani dan Rosidah dalam studi kepustakaan memberikan catatan kritis dalam MSDM yang dilakukan dalam sektor publik, pertama, tidak ada suatu ketentuan yang kuat yang mampu memberikan vonis terhadap pegawai khususnya dalam pemutusan hubungan kerja. Kedua, tekanan politik terhadap organisasi cukup besar dibandingan dengan swasta. Ketiga, perspektif waktu yang dimiliki oleh manajer publik biasanya lebih pendek baik dalam rangka pengambilan keputusan, perencanaan dan pengelolaan organisasi. Keempat, ruang lingkup pegawai yang teramat luas dan kompleks yaitu mencakup seluruh warga negara yang harus dilayani serta kompleksnya urusan yang harus diselenggarakan (Sulistiyani \& Rosidah, 2003). Selain itu terdapat pula kompleksitas lain yang terkait benturan antar nilai seperti nilai-nilai MSDM sektor publik yang terdapat lima nilai utama yaitu : 1) Hak asasi individu. 2) Efisiensi administratif. 3) Daya tanggap. 4) Keadilan sosial. 5) nasionalisme (Suharyanto \& Hadna, 2005). Nilai-nilai tersebut dapat saling berbenturan, sebagai fakta adalah bagaimana memenuhi nilai efisiensi dengan keadilan yang jelas keduanya sulit untuk disandingkan. Efisiensi mengenai menggunakan sumber daya untuk mencapai tujuan yang dapat diukur secara matematik sedangkan keadilan berbicara sesuatu yang abstrak yang harus dipenuhi di sektor publik dan dijelaskan secara kualitatif. Terkait dengan penilaian kinerja di sektor publik maka penilaian kinerja harus lebih banyak mempertimbangkan banyak faktor internal maupun eksternal dibandingkan dengan di 
sektor privat oleh kaena itu menyusun sistem penilaian kinerja di sektor publik sangat menantang dan sulit. Menurut (Van Thiel \& Leeuw, 2002): policy goals are often nonquantifiable and hard to measure. Tujuan dari kebijakan penilaian kinerja sendiri seringkali tidak dapat dikuantifikasikan dan sulit untuk diukur, itulah mengapa sektor publik lebih kompleks dan berat dari sektor privat.

\section{METODE PENELITIAN}

Pasca menentukan tujuan penelitian yaitu untuk memberikan deskripsi tentang berbagai tantangan dalam membangun manajemen kinerja maka diperlukanlah sebuah prosedur untuk mencari data tentang tantangan manajemen kinerja. Peneliti menerapkan studi literatur sebagai metode utama untuk mendapatkan data literatur dengan cara yang sistematis (Snyder, 2019). Pada akhirnya peneliti menginklusi kriteria literatur yang digunakan agar mendapatkan data yang sistematis sebagai batasan studi. Oleh karena itu peneliti menggunakan dua basis untuk melakukan screening literatur: Pertama, literatur tentang masalah internal manajemen dan pengukuran kinerja (inward looking); dan Kedua, masalah eksternal manajemen dan pengukuran kinerja (outward looking). Klasifikasi literatur dengan dua basis tersebut menghasilkan empat klasifikasi tantangan utama yaitu: pertama, dampak baik dan buruk; kedua, bias dan independensi penilaian; ketiga, disrupsi dan pandemi; dan keempat, milenial.

\section{HASIL DAN PEMBAHASAN}

Berbagai tantangan penilaian harus menjadi perhatian dalam manajemen dan pengukuran kinerja berdasarkan Undang-Undang (UU) Aparatur Sipil Negara (ASN) yang sudah berbasis merit. UU ASN memperkuat penerapan sistem merit dengan beberapa cara, antara lain: penerapan sistem rekrutmen berbasis merit, open carier system dalam setiap pengisian jabatan khususnya JPT, membentuk KASN selaku pengawal sistem merit, menghadirkan PPPK, reward \& punishment yang tegas dan berbasis kinerja, dan perlindungan dari intervensi politik (Prasojo \& Rudita, 2014). Khusus untuk sistem penilaian kinerja jangan sampai kembali pada era DP3 dahulu yang kurang tepat untuk menggambarkan kinerja ASN. Menurut (Prasojo \& Rudita, 2014): DP3 cannot be used 
as a performance indicators for two reason. First, the indicators are very abstract in nature, for instance. Loyalty and leadership and in an evaluation these cannot be tranformed into concrete indicators. Second, the evaluation process is very subjective as it is conducted by the head of the institution on the employees. Jangan sampai penilaian kinerja pada era UU ASN masih saja bersifat abstrak dan subyektif. Berikut ini adalah empat tantangan utama yang dapat menjadi input proses perbaikan terus-menurus dalam sistem manajemen dan pengukuran kinerja sektor publik di Indonesia.

\section{TANTANGAN 1: MENGELOLA DAMPAK BURUK DAN BAIK}

Tantangan manfaat melawan keburukan tersebut merupakan catatan kritis bagi pembuat sistem penilaian kinerja, jangan sampai terpaku pada manfaat yang diberikan tanpa memperhatikan konsekuensi lain yang ditimbulkan dari sistem penilaian, apalagi di sektor publik yang penuh dengan benturan nilai. Inti sebenarnya tantangan satu adalah sistem penilaian kinerja belum tentu menggambarkan realita yang sebenarnya dan justru dapat membatasi kinerja sebenarnya dari para pegawai. Secara teoritik inovasi justru dapat terhambat ketika sistem kinerja terlalu rigid dan mengekang (Van Dooren et al., 2015). Pada akhirnya jika dampak baik dan buruk sistem manajemen dan pengukuran kinerja tidak dikelola dengan baik justru akan membawa pegawai ke arah demotivasi dan menghasilkan kinerja yang negatif. Poin penting perubahan PP 36 Tahun 2019 ke PP Tahun 2019 adalah munculnya semangat mengapresiasi kinerja unggul dengan munculnya indikator kinerja tambahan selain indikator kinerja tambahan sehingga memberikan ruang fleksibilitas untuk bekerja beyond the target.

\section{TANTANGAN II: MENGELOLA BIAS DAN INDEPENDENSI PENILAIAN}

Pada era saat ini para Pegawai Negeri Sipil (PNS) sudah menggunakan aturan dari peraturan pemerintah nomor 46 tahun 2011 dan kemudian disempurnakan melalui melalui PP 30 Tahun 2019. Pada PP 46 tahun 2011, SKP sebagai instrumen utama memiliki permasalahan unsur subyektifitas dari pimpinan birokrasi yang dihindari untuk dapat membentuk penilaian yang benar-benar objektif, independen dan berintegritas, selain itu 
kelemahan lain adalah minimnya keterlibatan pegawai untuk berkolaborasi dengan pimpinan dalam menentukan sasaran kerja yang terjadi saat ini hanya untuk memenuhi aspek prosedural tanpa diskusi kolaboratif antar individu. Pendapat Condrey harus ada partisipasi dalam penilaian kinerja atau tugas akan berjalan sulit: Without participation and the legitimacy it entails, the performance appraisal task is more difficult (Condrey, 2005). Pada akhirnya pada PP 30 Tahun 2019 dimunculkan konsep penilaian 360 derajat yang berarti seorang PNS dapat dinilai oleh: Atasan langsung; pejabat yang ditugaskan menjadi atasan langsung PNS; rekan kerja setingkat; dan/atau bawahan langsung.

Pada akhirnya penilaian kinerja menurut PP 30 Tahun 2019 dibuat dengan meminimalisir subjektifitas dari para penilai sehingga sistem akan terjaga integritasnya. PP 30 Tahun 2019 telah menggunakan pendekatan komparatif dari berbagai sisi sudut pandang yaitu mengumpulkan subyektifitas-subyektifitas para penilai sehingga lebih obyektif karena melibatkan banyak penilai dengan harapan adanya konsistensi. Sistem penilaian dapat berupa penilaian 360 derajat dengan menilai individu oleh banyak penilai di sekitarnya.

\section{TANTANGAN III: MENGELOLA KINERJA DI ERA DISRUPSI DAN PANDEMI}

Berbagai sektor tengah mengalami himpitan dan pilihan sulit saat ini, berbeda dengan sektor privat yang sangat tertekan hingga mengalami kerugian dan pengurangan sumber daya manusia di masa pandemi ini, sektor publik mengalami tantangan berbeda dengan tetap wajib memberikan kinerja terbaik melayani masyarakat di tengah-tengah berubahnya cara kerja akibat disrupsi dan juga pandemi yang tidak kunjung selesai. Oleh karena itu sudah diperlukan penilaian kinerja yang adaptif untuk dapat memotret kinerja para pegawai di era digital dan working from home. Instansi publik di Indonesia memberikan penjadwalan ketat siapa saja yang harus hadir di kantor dan siapa yang tidak akan tetapi dengan pengawasan yang minimalis. Selain itu problem infrastruktur digital dan dampak psikologis dan sosiologis akibat telework juga dapat menyeret kinerja menjadi negatif (Schuster et al., 2020). Sistem informasi kinerja sudah seharusnya mengakomodasi teknologi digital yang berhasil diterapkan berbagai daerah dalam 
menginisasi aplikasi manajemen dan pengukuran kinerja baik berbasis aplikasi maupun website. Tentu jika hanya berbicara pada PP 30 tahun 2019 maka penilaian kinerja yang dilakukan masih dalam kondisi normal tanpa adanya problem akibat pandemi covid-19. Perlu penyesuaian konten pengukuran kinerja di mana harus adapatif pada pekerjaanpekerjaan digital yang sesuai dengan kondisi pandemi saat ini.

\section{TANTANGAN IV: MENGELOLA KINERJA GENERASI MILENIAL}

Per Desember 2018 piramida usia pegawai negeri sipil (pns) di Indonesia didominasi oleh kelompok usia 41-60 tahun dengan jumlah 2.896.821. Sedangkan pns dengan kelompok usia 18-40 tahun hanya berjumlah kurang dari separuhnya yaitu 1.288.682 (BKN, 2019). Kesenjangan generasi tersebut tentu menimbulkan problem serius dalam pelayanan publik di Indonesia, terutama kepada generasi millenial yang harus berurusan dengan para aparatur sipil negara dengan generasi yang berbeda.

Generasi yang berbeda tersebut cenderung akan berkonflik (Hubeis et al., 2018). Dalam berbagai kasus juga menunjukkan bahwa gap antar generasi yang terlalu jauh akan menyebabkan produktifitas yang rendah (Milligan, 2016). Bisa dibayangkan ketika generasi baby boomers dan generasi x yang sangat menjujung hirarki dan otoritas bekerja bersama dengan para millenial yang fleksibel dan pemberontak tentu kinerja yang optimal akan sulit untuk dicapai.

Sebagai backbone birokrasi dalam melayani masyarakat terutama penguasaan teknologi informasi sebagai sebagai native tentu sistem penilaian kinerja setidaknya memiliki sedikit perbedaan khusus untuk kaum milenial bukan berarti melakukan diskriminasi akan tetapi penyusunan sistem penilaian kinerja yang berbeda ini untuk menunjukkan bahwa mental dan cara kerja milenial yang berbeda sehingga reformasi birokrasi yang lebih sesuai dengan karakter mereka dapat tercapai dan bukan kembali ke budaya organisasi yang lama. Pada PP 30 tahun 2019 sebenarnya sudah difasilitasi konsep-konsep yang mencoba menyesuaikan dengan karakter perbedaan generasi terutama para milenial dengan munculnya indikator perilaku yang memasukkan inisiatif kerja dan pencapaian kinerja tidak hanya soal target akan tetapi juga inovasi atau implementasi ide baru yang dilakukan oleh pegawai. 


\section{MENGELOLA TANTANGAN SEBAGAI REKOMENDASI KRITIS}

Secara filosofis aturan penilaian kinerja diatur dalam bagian pembinaan kinerja. Pembinaan kinerja dalam ketentuan pasal 75 UU ASN menjelaskan bahwa penilaian kinerja PNS adalah bertujuan untuk menjamin objektivitas pembinaan PNS yang didasarkan padan sistem prestasi dan sistem karier. Sistem prestasi dimaksud dalam hal ini adalah setiap PNS mempunyai kriteria nilai tersendiri dalam pelaksanaan kinerja dan tanggung jawab yang melekat dalam dirinya sebagai sebuah proses penciptaan objektivitas dalam kerangka memaksimalkan kinerja yang lebih baik (Hayat, 2014). Objektivitas merupakan inti filosofis dari penilaian kinerja berdasarkan UU ASN yang berbasis merit, dengan kata lain saran utama aturan terbaru nanti harus mampu menjamin objektivitas dan mengurangi bias penilaian yang seringkali terjadi.

UU ASN memang memberikan jaminan pada sistem MSDM sektor publik yang berbasis merit dengan berbagai batasan yang jelas dalam hal khusus penilaian kinerja masih perlu aturan tambahan yang benar-benar komprehensif salain menghindari tantangan juga memberikan sistem yang jelas dalam laporan penilaian kinerja yang wajib digunakan untuk pengambilan keputusan. Ketika laporan kinerja baik maka indvidu dapat diberikan penghargaan tertentu dan jika buruk sanksi harus segera diberikan, hal ini untuk menjaga ritme kerja para PNS agar tidak kembali lagi seperti era PNS yang terkenal dengan kelambanannnya. Penegakkan sanksi ini sangat penting agar menimbulkan tekanan kerja yang lebih besar daripada sebelumnya sekaligus merubah budaya kerja secara signifikan. Pembaruan PP 46 tahun 2011 kepada PP 30 tahun 2019 telah memberikan tantangan-tantangan baru dalam implementasinya yang harus juga sesuai dengan perkembangan zaman terutama di era disrupsi dan pandemi termasuk mengelola para milenial dengan pandangan dan cara kerja yang berbeda. Penilaian kinerja harus menjadi instrumen utama dalam mengambil keputusan jangan kembali pada era suram lagi seperti dahulu ketika jamak dalam berbagai diskusi seorang PNS sangat sulit diberhentikan karena alasan tidak tercapainya kinerja (Prasojo \& Rudita, 2014). 


\section{KESIMPULAN DAN SARAN}

Di lingkungan yang kompleks dan penuh tekanan memang menyebabkan penilaian kinerja sektor publik sulit dan berat untuk dilakukan akan tetapi tetap harus dilakukan guna mencapai tujuan organisasi. Dalam konteks MSDM sektor publik di Indonesia yang tengah cerah ketika UU ASN muncul dan disertai dengan berbagai sistem manajemen dan pengukuran kinerja yang mengikutinya. Akan tetapi perlu untuk melihat berbagai tantangan yang muncul dengan cepat pada masa sulit ini.

Pertama, tantangan pengelolaan yang harus memperhatikan dua hal yaitu konsekuensi negatif dan positif dari penilaan kinerja. Selain itu yang kedua, tentang tantangan pengelolaan mengenai bias dan independensi penilaian yang harus memberikan jaminan bahwa penilaian harus menggunakan pendekatan komparatif. Kemudian yang ketiga, tantangan pengelolaan pada masa disrupsi dan pandemi di mana masalah baru muncul dalam era teknologi digital dan telework. Dan yang terakhir keempat bahwa tantangan pengelolaan manajemen dan pengukuran kinerja saat ini harus memperhatikan perbedaan generasi terutama titik tumpu pada generasi milenial.

Pada akhirnya studi ini dapat menjadi refleksi bersama tentang mengelola berbagai tantangan agar manajemen dan pengukuran kinerja PNS dapat secara tepat mengelola dan mengukur kinerja PNS, tidak berlebihan, tidak bias, sesuai dengan kondisi terkini dan memperhatikan perbedaan generasi pegawai.

\section{REFERENSI}

Badan Kepegawaian Negara. 2019. Statistik PNS per Desember 2018: Tenaga Guru dan Kesehatan Menjadi Fokus Pemenuhan Kebutuhan ASN. Siaran Pers Nomor : 058/RILIS/BKN/IV/2019.

Condrey, S. E. (2005). Handbook of human resources management in government. John Wiley \& Sons.

De Bruijn, H. (2007). Managing performance in the public sector. Routledge.

Hayat, H. (2014). PENINGKATAN KUALITAS SUMBER DAYA MANUSIA APARATUR PELAYANAN PUBLIK DALAM KERANGKA UNDANG UNDANG NOMOR 5 TAHUN 2014 TENTANG APARATUR SIPIL NEGARA. Civil Service Journal, 8(1 Juni).

Hubeis, M., Hermawan, A., \& Djohar, S. (2018). Generational conflicts at the Indonesian 
public sector workplace from the millennial's perspective. Polish Journal of Management Studies, 18.

Lane, J.-E. (2000). The public sector: concepts, models and approaches. Sage.

Masdar, S., Asmorowati, S., \& Irianto, J. (2009). Manajemen Sumber Daya Manusia Berbasis Kompetensi Untuk Pelayanan Publik. Airlangga University Press.

Miftah Thoha, M. P. A. (2016). Manajemen Kepegawaian Sipil di Indonesia Edisi Kedua. Prenada Media.

Milligan, R. S. (2016). Conflict and diversity associated with four generations in the workforce.

Prasojo, E., \& Rudita, L. (2014). Undang-Undang Aparatur Sipil Negara: Membangun Profesionalisme Aparatur Sipil Negara. Jurnal Kebijakan Dan Manajemen PNS, $8(1), 13-29$.

Pynes, J. E. (2008). Human resources management for public and nonprofit organizations: A strategic approach (Vol. 30). John Wiley \& Sons.

Rosyadi, S. (2007). IMBALAN BERBASIS KINERJA. Civil Service Journal, 1(1 Juni).

Schuster, C., Weitzman, L., Sass Mikkelsen, K., Meyer-Sahling, J., Bersch, K., Fukuyama, F., Paskov, P., Rogger, D., Mistree, D., \& Kay, K. (2020). Responding to COVID-19 through Surveys of Public Servants. Public Administration Review, 80(5), 792-796.

Snyder, H. (2019). Literature review as a research methodology: An overview and guidelines. Journal of Business Research, 104, 333-339.

Suharyanto, H., \& Hadna, A. H. (2005). Manajemen Sumber Daya Manusia. Media Wacana, Yogyakarta.

Sulistiyani, A. T., \& Rosidah. (2003). Manajemen sumber daya manusia: konsep, teori dan pengembangan dalam konteks organisasi publik. Graha Ilmu.

Van Dooren, W., Bouckaert, G., \& Halligan, J. (2015). Performance management in the public sector. Routledge.

Van Thiel, S., \& Leeuw, F. L. (2002). The performance paradox in the public sector. Public Performance \& Management Review, 25(3), 267-281. 